\title{
Fiqh Minority for Papuan Muslims in the Perspective of Maqasid al-Shari'ah
}

\author{
ABDURROHMAN KASDI*, MOHAMMAD WAHIB, UMMA FARIDA, \\ \& KHAMAMI ZADA ${ }^{1}$
}

\begin{abstract}
This article aims at describing the implementation of fiqh minority for Muslims in Papua with the perspective of Maqasid al-Shari'ah. The study used the qualitative method with the religious sociological approach considering that the study of fiqh minority has closely related to the religious development of the Papuan people. The results reveal that fiqh minority can be a solution for the Muslim minority community throughout Papua in practicing the teachings of Islam and living peacefully with the other adherent religions. The implementation of fiqh minority in the perspective Maqasid al-Shariah is closely related to the protection of Muslim minorities in predominantly non-Muslim areas. Some cases of applying the fiqh minority in Papua are related to the impurity of dog fur, saying Merry Christmas, the application of political fiqh, and marrying women of the Ahl al-Kitab such as Jews and Christians.
\end{abstract}

\section{Keywords: Fiqh Minority, Maqasid al-Shari ah, Maslahah, Changing of Law}

The idea of fiqh minority came along with the increasing number of Muslim immigrants coming to European countries, even on the American continent. The study of this fiqh minority in Arabic is known as Fiqh al-Aqalliyyat (Parray 2012: 88-89). The minority is a term for community groups in a country that is different from most of the country's population. The difference is in the form of differences in religion, sect, offspring, language, and other cases that distinguish between a group of humans and other humans (Seyranian, Atuel \& Crano 2008: 22-23). The emergence of the notion of fiqh minority originated from the phenomenon of Muslim minorities who lived in Europe and the United States of America (Najimdeen 2016:35).

The details of Muslim minorities in the European Continent are as follows: Indigenous Turks, Albanians, Kosovans, Croats, Serbs, Bulgarians, Europeans themselves who have just converted to Islam, Moroccan migrants in France, Turkish migrants in Germany, Indian migrants, Pakistanis, and Bangladesh in the UK. There are also Muslims in the Netherlands, Belgium, Austria, Italy, Spain, Scandinavian countries, and others (Kymlicka 2002: 1-6). While the details of Muslim minorities in the East such as Muslims in India, former Soviet Union namely Uzbekistan, Tajikistan, Kazakhstan, Azerbaijan, Muslims in Russia who come from Chechnya, Muslims in China, Ethiopian Muslims, Chad, minority in Thailand (Patani), Rohingya tribes in Myanmar, Sri Lanka, Nigeria and Ghana (Kazemipur 2017: 13-14).

Muslim minorities often find difficulties in practicing the teachings of Islam (Jubba, Pabbajah, Prasodjo, \& Qodir, 2019). On the one hand, they are required to be religious, but on

\footnotetext{
${ }^{1}$ Abdurrohman Kasdi* Ph.D. (Corresponding author), Director of the Postgraduate Program and lecturer at Dept. of Islamic Family Law, State Islamic Institute of Kudus, Jl. Conge No. 51, Ngembalrejo, Bae, Kudus, Jawa Tengah 59322, INDONESIA. Email: abdurrohmankasdi@iainkudus.ac.id; Mohammad Wahib, Ph. D., Dept. of Islamic Family Law, State Islamic Institute of Fattahul Muluk, Merah Putih Buper, Yabansai, Heram, 99224 Jayapura Papua, INDONESIA. Email: wahibstainjaya@gmail.com; Umma Farida, Ph. D., Dept. of Theology, State Islamic Institute of Kudus, Jl. Conge No.51, Ngembalrejo, Bae, Kudus, Jawa Tengah 59322, INDONESIA. Email: ummafarida@iainkudus.ac.id; Khamami Zada, Ph. D., Dept. of Constitutional Law, State Islamic University of Syarif Hidayatullah, Jl. Ir H. Juanda No.95, Cemp. Putih, Kec. Ciputat Tim., Kota Tangerang Selatan, Banten 15412, Jakarta, INDONESIA. email: khamami@uinjkt.ac.id.
} 
the other hand, they face obstacles because of their position as a minority in a different area of religion so that community life issues that related to political, economic, cultural, and fiqh (Islamic law) are often raised by Muslim minorities, both from indigenous people and immigrants (Masud 2001: 17).

Islam has a friendly concept to the environment. Islam brings peace to the entire world. The Messenger of Allah, Muhammad PBUH, was sent as the bearer of mercy to the universe. Likewise, the concept of changing Islamic law adapts to the changes in times and places so that the condition of Muslim minorities is different from the conditions of the majority Muslim (Kasdi, Nashiruddin, Farida, \& Praatmana, 2021: 96). Thus, this fiqh minority can be a solution for the Muslim minority community throughout the world to be able to practice the teachings of Islam, and live peacefully with different beliefs.

The condition of Muslim minorities living in Papua has similarities with Muslim minorities living in Europe or other countries. But the difference is that the Muslim minority of Papua is within the scope of the Republic of Indonesia whose majority of its followers carry out the teachings of Islam.

Figure 1:

Number of Population by Religion Adhered to in the Provinces of Papua and West Papua, 2021

\begin{tabular}{lccccc} 
Province & \multicolumn{5}{c}{ Number of Population According to Religion } \\
\cline { 2 - 6 } Papua & Islam & Protestant & Catholic & Hindu & Buddha \\
& 519.562 & 2.434 .467 & 864.133 & 3.425 & 2.560 \\
West Papua & $(13,59 \%)$ & $(63,67 \%)$ & $(22,59 \%)$ & $(0,09 \%)$ & $(0,06 \%)$ \\
& 416.656 & 614.325 & 98.777 & 2.155 & 2.155 \\
& $(36,74 \%)$ & $(54,17 \%)$ & $(8,71 \%)$ & $(0,19 \%)$ & $(0,19 \%)$
\end{tabular}

Source:

Data processed from the Ministry of Religious Affairs of Papua Province, Directorate General of Islamic Community Guidance, and Central Statistics Agency (BPS), July 2021.

Therefore, several cases are different from the problems of Islamic law experienced by Muslim minorities in Europe. For this reason, it is necessary to apply fiqh minority in Papua as has been done by Muslim minorities in Europe and the United States of America to maintain the religious harmony in Papua and avoid inter-religious conflict, so that Islam truly brings grace and peace to the universe.

\section{Theoretical Review}

Maqasid al-shari'ah in the study of usul fiqh means the objectives of the shari'ah and the secrets intended by Allah in every law of the legal order (Auda 2007: xxiii). The essence of the goal of shari'ah is to realize goodness for humans and eliminate the danger from them (jalb al-masalih wa dar' al-mafasid), while the basic principles of shari'ah (mabadi') are concerned with justice, equality, and independence as the noble values of Islam.

This theory was systematized and perfected by Abu al-Ishaq al-Shatibi, a Muslim intellectual who was born in the golden era of Islamic Andalusian civilization, Spain. The results of his research on the verses of the Quran and the Sunnah of the Prophet indicate that the teachings of Allah summarized in the two guidelines of the Muslim life are aimed at realizing the benefit and goodness of humanity, both in the world and in the hereafter. In his book entitled alMuwafaqat fi Usul al-Shari 'ah, he divided these maqasids into two parts; the purpose of God as the Creator of Shari'ah (Qasd al-Shari') and the purpose of man as the executor of the shari'ah (qasdu al-mukallaf) (Al-Shatibi 2012: 45).

Al-Shatibi then classified goodness of humanity (maslahat) into three parts, namely: primary (daruriyyah), secondary (hajiyyah), and tertiary (tahsniyyah). The primary interest (almaslahah al-daruriyyah) is everything whose existence is a necessity for the realization of the 
benefit of religion and the world. If this interest does not exist, it will cause the damage even loss of life, for example eating, drinking, praying, fasting, and others.

At the same time, al-Shatibi (2012: 48) also formulated five elements that must be maintained and realized to enforce this primary interest which is popularly called five universal principles (al-Kulliyat al-Khamsah), they are religious guarding (hifz al-din), self-care (hifz alnafs), mind guarding (hifz al-'aql), hereditary care (hifz al-nasl) and ownership protection (hifzal-mal). The universal principles in his view have a pattern of binary opposition, between existing and non-existent (Hanafi, 2002: 66). If these principles exist, then life on earth will go well. Conversely, if those principles are not there, then life will be threatened and damage (Hallaq \& Little 1991: 89).

Secondary needs (hajjiyyah) are the needs which, if not delimited, do not threaten human safety, but they will experience difficulties (Mahran 2009: 618). The existence of legal relief (rukhsah) can be an example of the concern of Islamic law for this need, not only in the matters of worship but also in the humanitarian relations (mu'amalah). Islam implies some legal relief if humans face difficulties in carrying out the commands of the shari'ah. In the humanitarian cases, Islam establishes various types of contracts, buying, selling, leasing, company (shirkah) and mudarabah (trading with people's capital agreements) and other legal reliefs in human relations. In the matter of criminal sanction ('uqubat), Islam presides over a fine for accidental murder and suspends a hand-cut for someone who steals because he was pressed to save his life from starvation.

Tertiary needs (tahsiniyyah) are the needs that do not reach the level of primary and secondary needs, but they are complementary to human needs such as all things which are propriety according to customs, avoid aspects that are not pleasing to the eye, or decorated with beauty according to the demands of norms and morals (Kasdi, 2019a: 260-261; Mahran 2009: 169). In various fields of life, such as worship, human relations, and criminal sanctions, God has guided all aspects related to tertiary needs. Islam implies purification of unclean creatures, both from the body and at the place and environment before carrying out worship. Islam recommends decoration when going to a mosque, recommends multiplying sunnah worship. In humanitarian cases, Islam forbids wasteful, miserable, raising prices, monopolies, and others. At the same time, Islam also stipulates the prohibition and punishments of killing children and women in warfare.

Imam Fakhruddin al-Razi (d. $606 \mathrm{H})$ states that Islam protects the five main principles above, without needing to look at what should take precedence (Al-Razi 1985). It is because, in addition to primary needs consisting of five subjects, there are also secondary and tertiary needs. Secondary needs aim to raise difficulties and alleviate the human condition when facing a problem. Such as relief for people who travel to combine (jama) and summarize the four Rak'ah prayers into two Rak'ahs, or sick people who are allowed to suspend their fasts. In this context, primary needs take precedence, then secondary needs. After this secondary needs, there are tertiary needs that related to the perfection of an act. This primary need to protect religion is the five daily prayers. If people just do the obligatory prayer, then that is true according to religious obligations. But if they want to get perfection and additives, so they are encouraged to perform sunnah prayers.

Whereas according to Saifuddin al-Amidi, maqasid daruriyyah takes precedence over maqasid hajiyyah, and maqasid hajiyyah takes precedence over maqasid tahsiniyyah. He also took precedence over the tertiary interest. The tertiary to fulfill primary interests should take precedence over tertiary interests to improve secondary purposes (Al-Amidi 1995: 143).

Specifically, Izzuddin Ibn Abd al-Salam (d. $660 \mathrm{H}$ ) examined in his book, Qawa'id alAhkam, the problem of maqasid studies related to the benefit and interest (maslahat). according to him, the purpose of shari'ah law is obtaining the benefit for human and avoiding the damage (mafsadat). Al-Quran serves to guide humans to seek goodness and all means to realize the maslahat, and also asks them to avoid the danger and all means that cause damage and breakage (Al-Salam 1991: 3). Thus, through maqasid al-shari ah, human destiny can be fulfilled 
by realizing its maslahat and avoiding mafsadat. The intended word of maslahat is every case that provides the benefits and eliminates the dangers. He also said that five elements to explore the advantages and goodness in the world and hereafter are religion, soul, mind, wealth, and descent. These five needs have been concluded based on the study (istiqra') on the branch (furu') laws that have the same purpose in protecting these five needs.

The five needs are a means to fulfill the humanitarian mission as a servant of God. AlShatibi emphasized that maslahat is the fulfillment of the five main goals of every creature of God which includes the protection of his religion, soul, mind, descendants, and wealth. In principle, every effort to realize the five maqasids is called maslahat. And conversely, every attempt to eliminate the five maqasids is categorized as mafsadat (Al-Shatibi 2012: 35).

In Islam, each maslahat and mafsadat vary in the level of urgency and importance. The first level, daruriyyah, which is the primary needs that must be fulfilled in human life. The unfulfilled of these needs will cause damage in life. The second level, hajjiyyah, the secondary needs that should be provided to prevent humans from difficulties. The absence of hajjiyyah will not threaten the existence of these five goals, but it still creates difficulties and hassles in human life. Whereas the third level, tahsiniyyah, is the complementary needs that support the improvement of one's dignity in society and before God. It aims to perfect the maintenance of the five main elements of maqasid al-shari'ah (Al-Shatibi 2012: 36).

Through this description of maqasid al-shariah, it can be deduced that Allah has arranged everything, both primary and complementary needs, and the purpose of the Shari'ah is to realize the benefit of mankind, eliminate the damage and maintain the sustainability of those five indicators of maqasid al-shari ah itself because this maqasid al-shari ah is the objectives of the shari'ah and the secrets intended by Allah in every law.

\section{The Research Methods}

The study aims to reveal the fiqh minority in maqasid al-shari'ah's perspective through data collection both in the library and in the field. It also attempts to describe the phenomenon of what is experienced by the Papuan Muslim community concerning behavior, perception, motivation, action, etc (Moleong 2007: 6). It uses qualitative methods with the religious sociological approach considering that this study of fiqh minority is closely related to the religious development of the local community. Along with this approach, social power and stratification influenced the religious impulse of a human. Therefore, it is expected to show the relationship between religion and society that occur in Muslim minorities in Papua Province (Kahmad 2000: 49-54). Besides, it also uses the analytical study method to explain the phenomena found in the field related to the implementation of fiqh minority for Papuan Muslims with the perspective of maqasid al-shari'ah and interpret its content, meaning, and essence more deeply (Muhadjir 1996: 3).

\section{Fiqh Minority for Muslims in Papua}

There are two classifications of the minority Muslims in Papua: First, the indigenous Papuans, namely the Dani tribe who converted to Islam and lived in the Walesi district of Jayawijaya Regency. They are the minority in the majority of the population in the central mountains of Jayawijaya. Second, immigrants from various regions outside Papua. They embraced Islam and lived in the Papua Province (Flower 2009). They migrate to work in Papua such as being an Indonesian State Army, Police, State Civil Servants, and entrepreneurs. Some live in Papua for preaching interest, such as religious teachers (ustaz|/da i) were sent by dakwah institutions in Indonesia (Lawson 2016: 509).

The implementation of the fiqh minority with the perspective of maqasid al-shari ah for Papuan Muslims appears in four cases: 


\section{Unclean Dogs and Pigs.}

According to the Maliki Mazhab, the hair and body of the dog are not unclean. The only thing that is unclean is licking his tongue. While Shafi'i stated that dog hair is as unclean as his saliva (Sabiq 1994: 50). In this Papuan fiqh minority context, the opinion of Imam Malik is more relevant to be followed because it contains maslahat. It is because of many neighbors around Papuan Muslims who keep dogs. Likewise the unclean law of pigs. Often a Muslim visits his neighbors who embrace other religions and raise the pigs. It cannot be avoided because of intensive interaction between neighbors, work colleagues and business relations.

In the Shafi'i Mazhab, pigs contain the heavy levels of unclean (mughallazah) which must be washed seven times, because they are likened to dogs. One of the cleansings has to mix with dust. The Papuan minority Muslims find it difficulty in practicing it. So, in this case, they tend to follow the opinion of Malik who loosely stated that pigs contain the intermediate levels of unclean (mutawassitah) which sufficiently washed once.

By following Malik's opinion, minority Muslim in Papua washes the household appliances with one wash. Thus, they have been considered clean and protected from being unclean. The opinion of Malik is more relevant than Shafi'i's opinion, so the existence of the fiqh minority for Papuan Muslims is the most suitable and superior way to avoid hardship. Moreover, the four schools are still included in the scope of the Ahl as-Sunnah wa al-Jama'ah, including the opinion of Malik who did not see the body and saliva of the unclean dog, except for his licks. This opinion is more relevant for Papuan minority Muslims who often interact with their neighbors in their daily lives who keep dogs in their homes (Firdaus 2019)

There was once a case, a Muslim laundry businessman in the city of Jayapura who asked the Fatwa commission of the Indonesian Ulama Council in the Papua Province. It related to the existence of customers who hand over their laundry to their laundry business. He found a lot of dog fur that was attached to the clothes of a Christian, while the clothes must be mixed with the same laundry. It became a dilemma because it was the opinion of the Malik school of thought which did not refer to skin and fur of the dog as unclean so that it became relevant to the daily lives of Muslim minorities in Papua.

\section{Christmas Greetings}

One of the phenomena that occur every Christmas celebration is the Christmas greetings that the Muslims say to Christians. It often leads to debate which is quite crowded every time ahead of the Christmas celebration. Likewise, non-Muslims visit the homes of Muslims on Eid al-Fitr and they wish them happy Eid al-Fitr. So, it is unavoidable when a Muslim repays his neighbor's kindness by visiting his Christian neighbor at Christmas.

The phenomenon of delivering the Christmas congratulations according to Yusuf alQaradawi is permissible as an expression of greetings (Tahniah). The reason is that it was a reply to the congratulations they gave during Eid al-Fitr based on the Qur'anic verse: "If you are respected by an honor, then respond with that which is better, or respond (with the same). Surely Allah takes into account everything" (al-Quran al-Nisa: 86). Likewise in the Surah alMumtahanah: 8, "Allah does not forbid you to do good and be fair to those who have not fought you because of religion and do not (also) expel you from your land. Verily Allah likes those who are just."

The Papuan Muslims are living side by side with non-Muslims who are willing to live peacefully, then Muslims must be good and also be fair to them (Tebay 2007: 339 \& 344). The Qur'an here describes the goodness (birr) and calls for our sincere kindness to them, as long as they are not related to their belief and worship. Even though parents are still non-Muslims, we are still obliged to do good with them.

The Ulama who allowed these greetings stated that the Christmas greetings were not a form of pledge or recognition of Christian beliefs. The opinions of various contemporary 
scholars are different from those of the ancient Salaf scholars who forbade Christmas congratulations. Ijtihad of contemporary scholars is different from other previous scholars (Kasdi, 2019: 254-255).

Al-Qaradawi also stated that changes in the current conditions demand the enactment of the law of its ability. He argued that Ibn Taymiyah used to prohibit saying Christmas greetings because the situation was different. If Ibn Taymiyyah lived in the present age with close Muslim and non-Muslim associations, he would change his opinion. Especially between siblings, school or campus friends, work colleagues, and neighbors.

In Egypt, Syaikh al-Azhar as al-Azhar's supreme leader routinely conveys Christmas congratulations to the highest leader of Coptic Christians in Alexandria (Al-Qaradawi 2012: 13). Including the Egyptian Mufti under the auspices of Egyptian Fatwa Institute, never banned Christmas congratulations to Christians.

If the relevance is related to the condition of the Muslim minority in Indonesia, such as in Papua and West Papua, then the ability of this Christmas congratulations gives concessions and conveniences (Flower 2008: 422-423). Not that it makes it easier for the Shari>'ah or recognizes their religious beliefs, but it is limited to the expression of greeting. For public officials, such as the President, Minister of Religion, Governors, Mayors, and Regents, it is only natural to say happy religious holidays. Likewise for husband and wife who are of different religions, fellow brothers and neighbors who have religious differences, then congratulating them is classified as good morals and values (Widiyanto 2015: 10). In the Prophet's hadith, it is mentioned that the characteristics of goodness are husn al-khulq (good morals) (Muslim 2001: 403). So, delivering the Christmas greetings in this context are considered as part of the good expression of morals. Especially in Papua, there is still a clash of conflicts between religions, especially between Muslims and Christians. They still need to maintain the situation to be conducive and avoid friction and explosion due to disharmony between the two religious followers. By allowing Christmas congratulation as a greeting, both Muslims and Christians can work together in realizing inter-religious mutual respect (Al-Payage 2019).

The Christmas greeting itself is not an acknowledgment of the truth of the Christian religion, nor does it pray for their salvation, but it is limited to congratulating them as a response to the greetings of Happy Eid al-Fitr delivered by Christians towards Muslims. For this reason, there is no question about it in terms of the law because it is in the scope of noble character and gentle preaching techniques to the Christian brothers.(Salim 2019) Such conditions often occur, such as during the Christmas open house, the Mimika Papua Police Chief who is a Christian, invites all members of the police regardless of religion to his home. As a subordinate member, they face a dilemma in congratulating Christmas. In this case, the opinion that allows saying that Christmas will find its relevance to be applied by the Papuan people (Ismail 2019).

$$
\text { Implementation of Siyasah (Political) Fiqh. }
$$

Fiqh minority also intersects with the problem of choosing non-Muslim in the election of regional leaders, such as governor and deputy governor of Papua who are the non-Muslim native Papuan. It becomes a dilemma for minority Muslim in Papua because there are views that forbid choosing non-Muslim leaders. While if they do not vote or participate in the elections, it is feared there will be tension and conflict between Muslims and non-Muslims. So in this fiqh minority, there is an opinion that the word awliya' referred to in Surah al-Maidah: 51 does not mean a leader but a loyal friend. So, it is still permissible to choose non-Muslim leaders.

Likewise, in the election of regents and legislative members of the Regional Representative Council, so far, both Muslims and Christians can compete to win the support of the Papuan people so that Muslims will no longer be antipathetic to abstention or absent from such these elections of governors and deputy governors, or mayors, regents, and their representatives, as well as being active in all elections. In some areas in Papua, candidates for regents and deputy regents are Christian, while Muslims who have spread to various remote areas in Papua are required to participate in the elections. Thus it is hoped that Muslims will 
continue to elect their leaders even though they are non-Muslims. It is to maintain common goodness and peace in the Papuan community (Mallu 2019).

Marrying women of the People of the Book (Ahl al-Kitab/Jews and Christians).

In the context of the $d a^{\prime} w a h$ process and the interaction of fellow Indonesian citizens, many Papuan women are married to Muslim men. Muslim immigrants who came to Papua do marriages with Papuan Christian women, based on the Quran (Surah al-Maidah: 5), that marrying Ahl al-Kitab women is permissible according to Jumhur Ulama (Sabiq 1994: 65).

The phenomenon of religious plurality in Papua makes the interaction between men and women unavoidable so that it can be possible for a Muslim marriage to Christian woman as long as the Islamic law permitted it.(Siswanto 2019) This opinion is relevant to be applied in the context of fiqh minority in Papua which allows married the Ahl al-Kitab women and recognizes that Jews and Christians today belong to the People of the Book (Ahl al-Kitab).

\section{The Application of Fiqh Minority by Papuan Muslims in the Perspective of Maqasid al-Shari'ah}

The implementation of fiqh minority in the perspective of Maqasid al-Shariah is closely related to the principles of daruriyyat, hajiyyat and tahsiniyyat . By considering Maqasid al-Shari ah, it will lead to peace in human life, namely the establishment of interactions between religious communities, especially Muslims and non-Muslims. The elastic teachings of Islam and become the basis of this fiqh minority will be well understood by the Muslim community. The impact, both individually and in society, will maintain harmony between religious communities. The application of fiqh minority by Papuan Muslims in the Perspective of maqasid al-shari'ah can be applied in the following issues:

\section{Unclean Dogs and Pigs}

First, the Principle of Daruriyyah. This principle is related to maintaining and upholding religion (hifz al-din) while continuing his embrace of faith as a Muslim. A Papuan Muslim can interact with neighbors, relatives, or friends of other religions without causing conflict due to religious differences. As a Muslim, he can love and allow the animals around them to live such as dogs and pigs, without having to hate, abuse, and even kill them. It is part of practicing Islamic teachings. In the Prophet's hadith, as a result of confining a cat without being fed, a woman eventually becomes a resident of hell. It is due to hatred towards animals such as cats. This case also includes dogs and pigs because these two animals are creatures of Allah. Thus, a person can enter heaven by giving a neighbor's thirsty dog to drink because the householder who has the dog left behind.

Second, the principle of hajjiyyah. In the Muslim minority community in Papua, domesticated dogs are very much found around their homes and neighborhoods. Likewise, the pigs used to roam around residential areas. As a Muslim who interacts with non-Muslim neighbors or friends, he will find it difficult to unclean dogs and their saliva and unclean pigs. It is because these two animals are used to roaming in residential areas. Therefore, they take the lightest religious school (mazhab). Namely, the opinion of Imam Malik who does not defile dog saliva. Unless the dog licks a saucer or container, it is considered unclean in the heavy category (mugallazah). It is so that the conditions experienced by them do not experience difficulties. This is according to what al-Shatibi conveyed in his book al-Muwafaqat (Al-Shatibi 2012: 56).

Often the harmonious relationship between neighbors is affected because of the uncleanness of dogs. Even dogs are often pelted with stones. This tolerance and harmony can be built with the insight of the Malik school. A Muslim in Papua can take this lighter opinion to avoid various difficulties, especially those related to dog saliva. 
Third, the principle of tahsiniyyah. Related to the uncleanness of dogs and pigs, they take Imam Maliki's opinion, it is included in the principle of Tahsiniyyah. Wahbah al-Zuhaili states that when this aspect of tahsiniyyah is lost, it will disappear good behavior (makarim al-akhlaq). Courtesy and morals with neighbors as well as friends and colleagues are often disturbed by dog problems. A neighbor may be rude to a neighbor who has dogs and pigs (Al-Zuhaili 2012: 1023).

\section{Christmas Greetings}

First, the principle of daruriyyah. In the ability to say a Merry Christmas to Papuan Muslims, harmony will be created between religious communities so that conflicts and disputes can be minimized among them. In this case, it is closely related to hifzal-nafs. In multi-religious countries, there are often misunderstandings in interfaith interactions. If harmony is not cultivated, it often becomes the seed of conflict and conflict that will take its toll and cause bloodshed. Thus, the preservation of soul and blood is part of the effort to maintain harmony between religious communities in Papua. It is what is meant by hifz al-nafs in the content of maqasid al-shari ah.

Second, the principle of hajjiyyah. This includes maslahat hajjiyyat. Masyaqqah or difficulties for Papuan Muslims will occur if there is a prohibition on saying Merry Christmas, for example: between relatives, classmates, neighbors, co-workers, and employees with their employers. It falls into the realm of hajjiyyat. If Muslims do not wish Christians a Merry Christmas, this will result in the strife between them. Thus, the product of this fatwa on survivability is based on the theory of maqasid, namely maslahat hajjiyyat. Qaradawi explains that his fatwa regarding the ability to say Merry Christmas rests on maqasid al-shari'ah, but does not ignore the text of the argument (Qaradawi 2006: 215).

Third, the principle of tahsiniyyah. In the realm of tahsniyyah, this Christmas greeting is a noble character. It is because it is a greeting or greeting as an expression of doing good to others. Papuan Christians wish a happy Eid al-Fitr to Muslims, then there is a reciprocity relation. Papuan Muslims say Merry Christmas to them. This Merry Christmas greeting is part of good morals that can be categorized as maslahat tahsiniyyat.

\section{Implementation of Siyasah (Political) Fiqh}

In this case, it allows Muslim minority Papuans to appear and be involved in the sector of politics in their territory. If viewed from the aspect of maqasid al-shari'ah, this can be explained as follows:

First, the principle of daruriyyah. The issue of participation in the political realm as an official in the executive and legislative branches is part of the concept of fiqh minority. Papuan Muslim minorities should not shy away from power. Precisely, by entering and being involved by being elected as a leader, they will be able to fight for the aspirations and interests of Muslims. Concerning maqasid al-shari'ah the principle of daruriyyah, it can be categorized as maintaining the religion (hifz al-din). Religion and politics are like two mature sides of money, they complement each other. The interests of ordinary Muslims are well preserved and accommodated. It is the meaning of safeguarding religion, which is included in hifz al-din. Maintaining the existence of Muslims is included in the embodiment of hifz al-din that is maslahat daruriyyat. Implicitly, the editor in the fatwa mentions the element of benefit, which is the goal of Islamic law (maqasid al-shari'ah) (Al-Shatibi 2012: 46).

Various cases in Muslim minority countries, such as Myanmar, the Uygur in China, the Patani in Thailand, and the Moro Muslims in the Philippines, show how the importance of the involvement of Muslims is in the political field. With the opening of the tap of democracy that is currently rolling out in various countries. For example, in the Middle East, the public has the authority to determine their involvement in the legislative elections to elect their representatives. If they are indifferent or avoid the hustle and bustle of politics, then the prospective leaders to be elected are non-Muslims. It is detrimental to Muslims, especially the 
issue of policies that do not take sides with Muslims. It is what is meant by safeguarding religion so that the religious life of Muslim minorities is guaranteed by the electability of Muslim representatives in their country.

The next aspect of daruriyyat is hifz al-mal or safeguarding property. If the Muslims in Papua do not have Muslim representation in the board or executive body, then this is a loss related to property. It is understood that the leader is the master of the budget. If the ruler of the budget is controlled by non-Muslims, it will harm the Papuan Muslim minorities.

Including if minority Muslims direct the choice to abstain (not voting), it will cause mafsadat or loss, in this case, property loss. The budget, which should have been used for the benefit of Muslims, was ultimately made difficult by a non-Muslim leader. They also limit the facilities for building places of worship and Islamic preaching. From this explanation, hifz al-mal is closely related to the participation of Muslims in the political sphere.

Second, the principle of hajjiyyah. The implementation of fiqh minority with maqasid alshari ah for Papuan Muslims is concerning to their involvement in the political sphere, is related to maslahat hajjiyyat. It means if Muslims ignored these needs, it causes difficulties, namely the difficulty of interacting between religious communities, especially Muslims and non-Muslims.

It is not easy to intensify communication between religious communities in Papua. Often there are horizontal conflicts caused by contact and friction between religious communities. With the involvement of Muslims in the political arena, there will be communication between Papuan Muslim elites who sit in the legislative and executive branches with the majority of nonMuslims. With this smooth communication, there will be a convenience in all aspects of life. The difficulties caused by a lack of communication and interaction disappear. It is part of the realm of hajjiyyat which contains efforts to eliminate difficulties in the lives of minority Muslims.

This intensive communication should not only be carried out by the elite but can be extended to subordinates and the wider community. When a Muslim representative has been elected to be the leader in Papua, this can be a role model and an example that can teach the principle of tasamuh or tolerance to other Muslims, instead of suspecting mutual suspicion that will result in conflict. The role of this political figure will greatly influence society. They can transmit a harmonious attitude to life side by side to fellow citizens of different religions.

With smooth communication, mutual respect and respect will be created and lead to peace and convenience in everyday life. On the other hand, if the products of this fiqh minority fatwa are still not well understood by the Muslim minority in Papua, they will avoid the political sphere, which in the end, will harm Muslims themselves. Besides, it will also plunge them into difficulties that contrary to the principle of maslahat hajjiyyat.

Third, the principle of tahsiniyyah. It is related to morals or polite interactions between Muslims and non-Muslims. With the reluctance of Papuan Muslims to become legislative and executive candidates, this is a cover for the gentle attitude towards fellow Muslims. Allah emphasized in the Quran that the interaction between Muslims and non-Muslims should be directed to the nature of birr (doing good) and iqsat) (fair). The attitude of doing good and fairness must continue to be nurtured and maintained in multicultural life, including multireligion that occurs between the Muslim minority and the non-Muslim majority. With this attitude, the Muslim minority has expressed the goal of Islamic law, namely maqasid al-shari'ah, namely maslahat tahsiniyyat by maintaining morals towards the majority non-Muslim.

Their participation of Muslims in political life is a form of sympathy and attention to the reality of their social life. Including good morals is a friendly and polite attitude towards the majority of non-Muslims. With this participation, they do not indulge in an exclusive attitude by avoiding participating in using their voting rights in general elections. With an open attitude, willing to mingle in social life and actively participate in the political arena, will foster an open attitude and show good morals. It will also realize harmonious life in the community.

Thus, maslahat tahsiniyyat will be preserved and applied in the lives of minority Muslims. The benefits of this benefit will return to Muslims themselves. Gradually, Papuan Muslim minorities will be involved and get a share of power with gentle preaching and good 
morals. Papuan Muslims will occupy seats as representatives of the people in parliament and occupy posts of public office in the executive branch of government. They will be able to achieve various important positions. On the other hand, if the attitude based on maslahat tahsiniyyat is not applied, it will cause conflict in society.

\section{Marrying a Woman of the Book (Ahl al-Kitab)}

In this case, a Muslim man may marry a Christian Papuan woman. In this marriage, a Muslim husband can have the opportunity to invite his wife to embrace Islam (Farida \& Kasdi, 2021: 172-174). Papuan women who live with Muslim husbands will be attracted to Islam with their Muslim husbands. It usually occurs through her husband's gentle invitation to introduce Islam and her husband's polite behavior in the household. It is the secret or wisdom of the ability of Muslim men to marry women Ahl al-Kitab (Sabiq, 1994: 2: 45). In this connection, there is the principle of daruriyyat in the maqasid al-shari ah, namely hifz al-din, namely maintaining Islam, in the sense that it has the opportunity to convert Christian Papuan women.

The privilege of this marriage can open up opportunities for the gradual spread of Islam in Papua. Of course, voluntarily, gently, and without coercion (Farida \& Kasdi, 2018: 144-145). With a gentle way of preaching bilhal, it will be possible for the wife to be attracted to convert to Islam. It contains the principle of tahsiniyyat which is related to the maqasid al-shari ah.

To conclude, fiqh minority is a solution for the Muslim minority community throughout Papua so that they can practice the teachings of Islam, while still living peacefully with the surrounding environment with different beliefs. The benefits of fiqh minority are spreading the universal values of Islam and maqasid al-shari'ah to the non-Muslim community, moral support to minority Muslims, and protecting them in predominantly non-Muslim areas. The direction of this fiqh minority is adjusted to the Medina Charter, where the Prophet PBUH accommodated non-Muslim who lived peacefully side by side with Muslims, by respecting their rights.

Thus, the teachings of Islam that have elasticity and become the foundation of fiqh minority with the perspective of maqasid al-shari'ah can help Muslim minority groups in responding to contemporary problems faced in non-Muslim communities. In the Papuan context, it helps religious practices for Muslim minority communities as individuals, families, and communities, besides of helping them in maintaining their existence as Muslims who must carry out the Shari'ah as a whole, as well as making it easier for the minorities to carry out the obligation and deliver the Islamic treatises to non-Muslims in acceptable ways.

\section{References}

Al-Amidi. 1995. Al-Ihkam fi Ushul al-Ahkam (II). Beirut: Dar al-Fikr.

Al-Payage, S. I. 2019. Interview about the Merry Christmas is allowed as Tahniah with the general chairman of the Indonesian Ulama Council (MUI). Secretariat of MUI Papua.

Auda, J. 2007. Maqasid al-Shariah as Philosophy of Islamic Law: A Systems Approach. London: The International Institut of Islamic Thougth.

Farida, U., \& Kasdi, A. 2018. The 2017 KUPI Congress and Indonesian Female Ulama". Journal of Indonesian Islam (JIIS), 12(2), 135-158. https://doi.org/10.15642/JIIS.2018.12.2.135-158

Farida, U., \& Kasdi, A. (2021). Women's Roles in Ihyā' 'Ulūm al-Dīn and Method of Teaching it at Pesantrens in Indonesia. Al-Jami'ah, 59(1), 163-190. https://doi.org/10.14421/ajis.2021.591.163-190

Firdaus, A. 2019. Interview about Imam Malik's Fatwa on the Status of the Body and Saliva of Dogs with the chairperson of the fatwa commission of the Indonesian Ulama Council (MUI), Papua Province. Secretariat of MUI Papua.

Flower, S. 2008. Muslims in Melanesia: putting security issues in perspective. Australian Journal of International Affairs, 62(3), 408-430. https://doi.org/10.1080/10357710802286841

Flower, S. 2009. The Struggle to Establish Islam in Papua New Guinea (1976 - 83). The Journal of Pacific History, 44(3), 241-260. https://doi.org/10.1080/00223340903356823 
Hallaq, W. B., \& Little, D. P. (Eds.). (1991). The Primacy of The Qur'an in Shatibi Legal Theory. In Islamic Studies. Leiden: EJ. Brill.

Hanafi, H. (2002). Maqasid al-Shari'ah wa Ahdāf al-Ummah, Qira'ah fi al-Muwafaqat li al-Shatibi. Jurnal Al-Muslim Al-Mu'ashir, 26(103), 65-102.

Ismail, W. (2019). Interview about Tradition in saying Merry Christmas to the Staff to his Superior or vice versa with one of the Timika police officers, Mimika Regency, Papua.

Jubba, H., Pabbajah, M., Prasodjo, Z. H., \& Qodir, Z. (2019). The Future Relations between the Majority and Minority Religious Groups, Viewed from Indonesian Contemporary Perspective: A Case Study of the Coexistence of Muslims and the Towani Tolotang in Amparita, South Sulawesi. International Journal of Islamic Thought, 16(2), 13-23.

Kahmad, D. (2000). Metodologi Penelitian Agama. Bandung: Pustaka Setia.

Kasdi, A. 2019a. Actualizations of Maqāşid Al-Shariah in Modern Life; Maqāşid Al-Shariah Theory as a Method of The Development of Islamic Laws and Shariah Economics. Justicia Islamica Jurnal Kajian Hukum Dan Sosial, 16(2), 247-268. https://doi.org/10.21154/justicia.v16i2.1666

Kasdi, A. 2019b. Reconstruction of Fiqh Nusantara: Developing the Ijtihad Methodology in Formulating Fiqh from Indonesian Perspective. QIJIS: Qudus International Journal of Islamic Studies, 7(2), 239-266. https://doi.org/10.21043/qijis.v7i2.4797

Kasdi, A., Nashiruddin, M., Farida, U., \& Praatmana, N. D. 2021. Potential of Kudus as a New International Pilgrimage Destination in Indonesia: Halal Tourism Optimising Local Wisdom. International Journal of Religious Tourism and Pilgrimage, 9(1), 96-105. https://doi.org/https://doi.org/10.21427/6a93-zn19

Kazemipur, A. (2017). Reckoning with the Minority Status: On Fiqh al-Aqalliyyat al-Muslema (Jurisprudence of Muslim Minorities). Muslim Community Organizations in the West, 53(4), 13-14. https://doi.org/10.1007/978-3-658-13889-9

Kymlicka, W. (2002). Multiculturalism and Minority Rights: West and East Multiculturalism and Minority Rights: West and East. Journal on Ethnopolitics and Minority Issues in Europe, 12(4), 1-26. Retrieved from https://www.ecmi.de/fileadmin/downloads/publications/ JEMIE/2002/nr4/Focus4-2002_Kymlicka.pdf. Accessed on May 3, 2021.

Lawson, S. (2016). West Papua, Indonesia and the Melanesian Spearhead Group: competing logics in regional and international politics. Australian Journal of International Affairs, 70(5), 506-524. https://doi.org/http://dx.doi.org/10.1080/10357718.2015.1119231

Mahran, M. B. (2009). Mausu'at al-Tasyri' al-Islami. Cairo: Majlis al-A'la.

Mallu, M. (2019). Interview about Maintain Peace during general and regional elections in the Papuan Community with members of the DPRP (Papuan People's Representative Council).

Masud, M. K. (2001). Islamic Law and Muslim Minorities. Law and Society, (June), 17. Retrieved from

https://openaccess.leidenuniv.nl/bitstream/handle/1887/16826/ISIM_11_Islamic_Law_a nd_Muslim_Minorities.pdf?sequ. Accessed on June 3, 2021.

Moleong, L. (2007). Metodologi Penelitian Kualitatif (XXIII). Bandung: Remaja Rosdakarya.

Muhadjir, N. (1996). Metodologi Penelitian Kualitatif (VII). Yogyakarta: Rake Sarasin.

Muslim. (2001). Shahih Muslim. Beirut: Dar al-Fikr.

Najimdeen, B. (2016). From the Fiqh of Minority to Cosmopolitan Fiqh: An Analysis of European Muslim Struggle. Policy Perspectives, 33-46. https://doi.org/DOI: 10.13169/polipers.11.1.0033

Parray, T. A. (2012). The Legal Methodology of "Fiqh al-Aqalliyyat" and its Critics: An Analytical Study. Journal of Muslim Minority Affairs, 32(1), 87-107. https://doi.org/http://dx.doi.org/10.1080/13602004.2012.665624

Al-Qaradawi, Y. 2006. Dirasah fi Fiqh Maqasid al-Shari'ah; baina al-Maqasid al-Kulliyah wa alNushus al-Juz'iyyah. Cairo: Dar al-Syuruq.

Al-Qaradawi, Y. 2012. Fī Fiqh al-Aqalliyyat (I). Cairo: Dar al-Syuruq.

Al-Razi, F. 1985. Al-Mahshul (I). Beirut: Dar Al-Kutub Al-Islamiyyah. 
Sabiq, S. (1994). Fiqh al-Sunnah. Beirut: Dar al-Fikr.

Al-Salam, I. bin A. 1991. Qawa'id al-Ahkam Fì Mashalih Al-Anam. Cairo: Maktabah Kulliyyah Azhariyyah.

Salim, N. (2019). Interview about Noble Morals and the Soft Preaching Technique to Christian Brothers with the board members of the FKUB (Forum for Religious Harmony) Keerom Regency. Secretariat of FKUB Keerom.

Seyranian, V., Atuel, H., \& Crano, W. D. (2008). Dimensions of Majority and Minority Groups. Group Processes \& Intergroup Relations, 11(1), 21-37. https://doi.org/10.1177/1368430207084843

Al-Shatibi, I. ibn M. 2012. Al-Muwafaqat fi Ushul al-Shari'ah. Qatar: Centre for Muslim Contribution to Civilization, Qatar Foundation.

Siswanto, E. (2019). Interview about Marriage Different Religion in Papua with members of the FKUB (Forum for Religious Harmony) Jayapura City. Secretariat of FKUB Jayapura.

Tebay, N. (2007). 'Papua, the Land of Peace': The Interfaith Vision and Commitment for West Papua. Exchange BRILL, 36(1), 337-358. https://doi.org/10.1163/157254307X225025

Widiyanto, A. (2015). Female Religious Authority, Religious Minority and The Ahmadiyya: The Activism of Sinta Nuriyah Wahid. Journal of Indonesian Islam, 09(01), 1-24. https://doi.org/10.15642/JIIS.2015.9.1.1-24

Al-Zuhaili, W. 2012. Ushul al-Fiqh al-Islamiy. Beirut: Dar al-Fikr. 